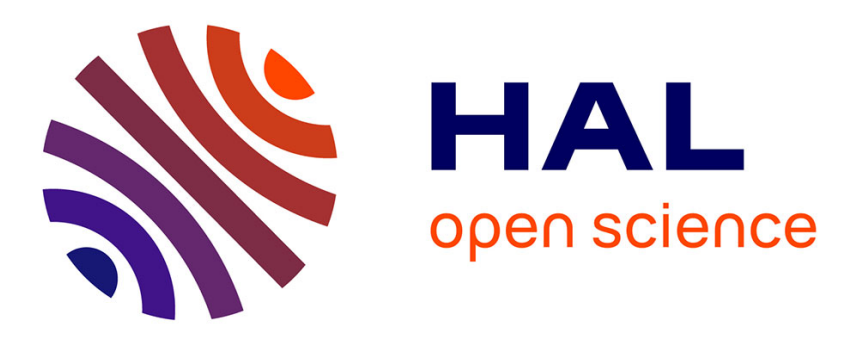

\title{
Orchid bee (Hymenoptera: Apidae: Euglossini) assemblages from three different threatened phytophysiognomies of the subtropical Brazilian Atlantic Forest
}

Douglas Caldeira Giangarelli, Willian Moura De Aguiar, Silvia Helena Sofia

\section{To cite this version:}

Douglas Caldeira Giangarelli, Willian Moura De Aguiar, Silvia Helena Sofia. Orchid bee (Hymenoptera: Apidae: Euglossini) assemblages from three different threatened phytophysiognomies of the subtropical Brazilian Atlantic Forest. Apidologie, 2015, 46 (1), pp.71-83. 10.1007/s13592-0140303-4 . hal-01284424

\author{
HAL Id: hal-01284424 \\ https://hal.science/hal-01284424
}

Submitted on 7 Mar 2016

HAL is a multi-disciplinary open access archive for the deposit and dissemination of scientific research documents, whether they are published or not. The documents may come from teaching and research institutions in France or abroad, or from public or private research centers.
L'archive ouverte pluridisciplinaire HAL, est destinée au dépôt et à la diffusion de documents scientifiques de niveau recherche, publiés ou non, émanant des établissements d'enseignement et de recherche français ou étrangers, des laboratoires publics ou privés. 


\title{
Orchid bee (Hymenoptera: Apidae: Euglossini) assemblages from three different threatened phytophysiognomies of the subtropical Brazilian Atlantic Forest
}

\author{
Douglas Caldeira Giangarelli ${ }^{1,2}$, Willian Moura de Aguiar $^{3}$, Silvia Helena SofiA ${ }^{2}$ \\ ${ }^{1}$ Programa de Pós-Graduação em Ciências Biológicas, Universidade Estadual de Londrina, Londrina, PR, Brazil \\ ${ }^{2}$ Departamento de Biologia Geral, Centro de Ciências Biológicas, Universidade Estadual de Londrina, Rodovia Celso \\ Garcia Cid, km 380, 10011, 86057-970, Londrina, PR, Brazil \\ ${ }^{3}$ Laboratório de Estudos Ambientais, Programa de Pós-Graduação em Modelagem em Ciências da Terra e do Ambiente, \\ Universidade Estadual de Feira de Santana, Av. Transnordestina s/n, Novo Horizonte, 44036-900, Feira de Santana, BA, \\ Brazil
}

Received 25 February 2014 - Revised 10 May 2014 - Accepted 19 June 2014

\begin{abstract}
Euglossine bees were sampled in three different phytophysiognomies [Rainforest (RF), Mixed Forest (MF) and Seasonal Semi-Deciduous Forest (SF)] of Brazilian Atlantic Forest (AF). In this study, euglossine males attracted to eight synthetic scent baits were captured with an entomological net. Results revealed different euglossine bee assemblages associated with three AF ecosystems surveyed. A higher richness (14 spp.) of euglossines was found in the RF, followed by SF (seven spp.) and MF (three spp.) forests. Surprisingly, despite the short distance between MF and SF and that both forest remnants were located in the same studied region and under the same climatic conditions, the species richness detected was lower in MF than in SF. The present study contribute to greater knowledge of euglossine assemblages in remnants of Atlantic Forest areas composed of MF, SF and RF, helping to further understand how the structure of these bee assemblages can vary significantly at the local and/or regional level. In addition, our findings also represent a contribution to the understanding to the orchid bee biogeography.
\end{abstract}

euglossine bees / seasonal semi-deciduous forest / tropical rain forest / mixed forest / neotropical forests

\section{INTRODUCTION}

Euglossine bees, also known as orchid bees due to their close relationship to more than 700 species of orchids in the Neotropics, constitute a group of pollinators native to the New World tropics

Electronic supplementary material The online version of this article (doi:10.1007/s13592-014-0303-4) contains supplementary material, which is available to authorized users.

Corresponding author: S. Sofia, shsofiabelh@gmail.com

Manuscript editor: James Nieh
(Roubik and Hanson 2004), a region of the world that has undergone drastic rates of deforestation over the past centuries (Wright 2005). As a result of deforestation in the South American portion of the Neotropical region, nowadays, the Brazilian Atlantic Forest (AF) is one the most threatened forests in the world. Originally covering around $1,500,000 \mathrm{~km}^{2}$, the AF is now reduced to about $15 \%$ of its original extension (Ribeiro et al. 2009).

Widely recognized as one of the most important and threatened biodiversity hotspots on the planet (Myers et al. 2000), the Brazilian Atlantic Forest is distributed into tropical and subtropical regions, extending through a wide latitudinal and 
longitudinal range, which have favored high levels of diversity and endemism in both fauna and flora (Ribeiro et al. 2009).

There are more than 50 orchid bee species (i.e., about $25 \%$ of the known orchid bee richness), throughout the Atlantic Forest domain, one-half of which is considered endemic to this threatened tropical American biome (Nemésio 2009). Although the knowledge of euglossine richness and distribution across AF has deeply improved in the last decades (Wittmann et al. 1988; Rebêlo and Garófalo 1991; Nemésio 2009; Cordeiro et al. 2013), recent studies have continuously reported new euglossine species across the AF domain (Nemésio 2009, 2010; Faria and Melo 2012). At the same time, information about the geographical distribution of some euglossine species has also increased (Nemésio 2010; Giangarelli and Sofia 2011; Nemésio 2012). Based on this, it has been suggested that additional surveys across the AF domain are still necessary to gain better knowledge about the euglossine fauna richness in this biome (Nemésio 2009), and to improve our understanding of the geographic distribution of many orchid bee species, including those with apparent limited distribution (Nemésio 2010).

Previous studies have shown that the AF latitudinal range is around $29^{\circ}$ (Ribeiro et al. 2009) and that the diversity of the orchid bee fauna decreases from northern to southern South America (Wittmann et al. 1988; Nemésio 2010; Mattozo et al. 2011). However, the Atlantic Forest areas in southern Brazil have been poorly surveyed so far. A recent study carried out on the coastal areas of the Atlantic Forest revealed the occurrence of only six euglossine species in a large remnant of the AF (Mattozo et al. 2011), a number of species that is much lower than those reported for sites in southeastern and northeastern Brazil (Tonhasca et al. 2002; Nemésio 2010; Cordeiro et al. 2013). Despite their finding, Mattozo et al. (2011) propose the existence a higher diversity of orchid bee fauna in the studied region. Taking into consideration that the region where these authors accomplished their study belongs to the Corredor de Biodiversidade da Serra do Mar, one of the richest areas in biodiversity of the Brazilian Atlantic Forest (Aguiar et al. 2003), more efforts should be made to survey euglossine diversity in this region. Also, if we consider the heterogeneous environmental conditions across the AF domain and the different types of phytophysiognomies constituting this Neotropical biome, local studies concerning the orchid bee communities throughout the AF areas are extremely relevant for future conservation measures to protect the euglossine biodiversity. It is generally accepted that the knowledge of species diversity, as well as the impact of biotic and abiotic factors on species richness and distributions, are critical matters in conservation biology (Petersen and Courtney 2010).

In this sense, the current study aimed to survey the richness, abundance and diversity of orchid bees in three different phytophysiognomies of the Brazilian Atlantic Forest in southern Brazil, which comprise the Rainforest (RF), the Mixed Forest (MF) and the Seasonal Semi-Deciduous Forest (SM), where these types of vegetation are prevalent (Morellato and Haddad 2000). Nowadays, remnants of these three forest ecosystems in southern Brazil exist in a fragmented landscape (Ribeiro et al. 2009), representing the last refuges of the local biodiversity.

\section{MATERIALS AND METHODS}

\subsection{Study areas}

a) "Reserva Natural Salto Morato" (hereinafter called RNSM) - 2509'36" S and 48 $18^{\prime} 02^{\prime \prime}$ $\mathrm{W}$, located in the municipality of Guaraqueçaba, on the coastal region of the State of Paraná, southern Brazil (Figure 1). Presenting an area of about 2,340 ha, mostly covered by Rainforest (RF), the RNSM is located within the APA (Área de Proteção Ambiental = Environmental Conservation Area) of Guaraqueçaba (Straube and Urben-Filho 2005), which is currently part of the largest existing remnant of Atlantic Rainforest in Brazil (Galindo-Leal and Câmara 2003). The local climate is classified as $C f a$ (Köppen), or humid subtropical climate. The average annual temperature is $21^{\circ} \mathrm{C}$. The rainfall rates are above 2,000 $\mathrm{mm}$ per year and annual average relative air humidity is $85 \%$. The altitude varies between 25 and $930 \mathrm{~m}$ (Santos-Pereira et al. 2011). 


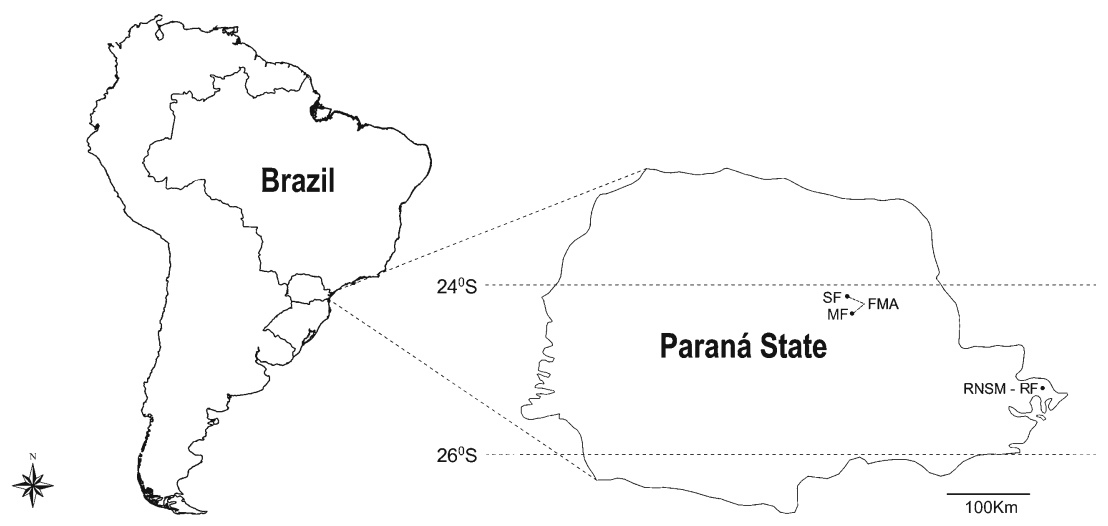

Figure 1 Map showing the location of both 'Fazenda Monte Alegre' (FMA) and 'Reserva Natural Salto Morato' $(\mathrm{RNSM})$ in the State of Paraná, southern Brazil. $\mathrm{RF}=$ Dense Forest; SF = Seasonal Semi-Deciduous Forest; MF = Mixed Forest.

b) "Fazenda Monte Alegre (hereinafter called FMA)", located at an altitude of $885 \mathrm{~m}$, $24^{\circ} 12^{\prime} 42^{\prime \prime} \mathrm{S}$ and $50^{\circ} 33^{\prime} 26^{\prime \prime} \mathrm{W}$, in the municipality of Telêmaco Borba, central eastern region of the State of Paraná (Reis et al. 2005), and belonging to Klabin S.A. The region is inserted in the limit of two types of climate: $C f a$ and $C f b$-Köppen classification-(Miretzki 2003). The average annual temperature and rainfall registered for the region are $19.5{ }^{\circ} \mathrm{C}$ and $1,478 \mathrm{~mm}$, respectively (Reis et al. 2005). The FMA comprises a total area of 126,000 ha, of which $37 \%$ of this area is covered by native vegetation, including the following phytophysiognomies: Mixed Forest (MF) and Seasonal Semi-Deciduous Forest (SF). The other part of the vegetation present on FMA corresponds to cultivated areas of Pinus sp and Eucalyptus sp. used in the wood industry. These areas are in direct contact with the limits of the native vegetation areas of MF and SF, which are frequently encircled by cultivated areas (Reis et al. 2005). In our study, we selected two sites on FMA to survey the euglossine bees: a Seasonal SemiDeciduous Forest (SF: 2405'11" S, 5041'55" W) fragment of about 217 ha and an area (7,900 ha) of Mixed Forest (MF: 2417'03” S, $50^{\circ} 35$ '20” W). Both areas were $24 \mathrm{~km}$ far from each other. However, after we finished our samplings, the SF native vegetation area was partially destroyed for the construction of a Hydroelectric Power Plant (HPP) near this area.

\subsection{Sampling}

The sampling method was based on Giangarelli et al. (2009), with some modifications. During the surveys, male euglossine were attracted by scent baits of eight different fragrances (eucalyptol, eugenol, vanillin, benzyl acetate, benzyl benzoate, methyl salicylate and methyl cinnamate) and collected with an entomological net. In both reserves (RNSM and FMA), bees were collected once a month, between 10:00 and 13:30 h, simultaneously by two collectors positioned at two different sites (1 and 2) in each study area. The distance between both collectors in each study area varied from 250 to $500 \mathrm{~m}$.

On the FMA, the samplings were carried out from March 2008 to February 2010. However, during June and July 2008 and June, July and August 2009, which are months of low temperatures in the region, no sampling was performed in either study area (SF or MF).

At the RNSM, bees were sampled from April 2009 to May 2010 in two different locations $\left(\mathrm{SA}_{\mathrm{RF}}\right.$ $25^{\circ} 10^{\prime} 12^{\prime \prime} \mathrm{S}-48^{\circ} 17^{\prime} 98^{\prime \prime} \mathrm{W}$, and $\mathrm{SB}_{\mathrm{RF}}-25^{\circ} 10^{\prime} 57^{\prime \prime} \mathrm{S}-$ $48^{\circ} 18^{\prime} 20^{\prime \prime} \mathrm{W}$ ) apart $2.3 \mathrm{~km}$, which were surveyed on consecutive days, to ensure the improvement of our sampling effort. Thus, we duplicated our sampling effort in the RF. Also, due to adverse weather conditions, no sampling was performed in June 2009 in either RF areas $\left(\mathrm{SA}_{\mathrm{RF}}\right.$ or $\left.\mathrm{SB}_{\mathrm{RF}}\right)$ at the RNSM, and in April 2009, September 2009, January 2010, February 2010 and May 2010, due to successive rainy days, it was possible to perform only one day of sampling in RF areas. Therefore, in a period of 14 months of study at the 
RNSM, from the 28 samplings days scheduled to be carried out in RF areas, a total of 21 surveys were performed. Due to the same reason, it was not always possible to perform two days of samplings in each FMA study area. Thus, on the FMA, 19 surveys were carried out in the area of Semi-Deciduous Forest, and only 15 samplings were performed in the area of Mixed Forest. In February 2009, May 2009, October 2009 and February 2010 , samplings were not performed in this area because it rained during the surveys.

In our study, a two-hour survey was accomplished on the FMA, while at the RNSM, the surveys lasted three hours. Since two sites were simultaneously surveyed by two collectors, we calculated four hours for each sampling day in both the SF and MF and six hours in the RF remnant. To homogenize variations in the sampling effort in these areas, the number of bees collected in each area was divided by the number of hours of sampling in each type of vegetation.

The bees collected during the surveys were labeled and identified in the laboratory, and voucher specimens of all species were deposited in the Museu de Zoologia of the Universidade Estadual de Londrina (MZUEL).

\subsection{Data analysis}

As stated above, for analyses considering bee abundance and richness, we divided the number of individuals and species collected per site by the number of sampling hours (Giangarelli et al. 2009; Abrahamczyk et al. 2011), to compensate for unequal sampling effort.

To evaluate sampling efficiency for the estimation of species richness in RF, SF and MF, rarefaction curves of species for each of these three study sites were generated using the software EstimateS 8.0 (Colwell 2006). This software was also employed to calculate the potential number of species for the three studied areas using non-parametric richness estimators (Jack1 and Bootstrap).

Species diversity and evenness were calculated using the indices of Shannon-Wiener (H') and Pielou (J'), respectively (Ludwig and Reynolds 1988). The dominance index of the Berger-Parker $\left(\mathrm{d}_{\mathrm{BP}}\right)$, obtained through the relative abundance of the most common species in the study area, was employed to obtain an estimate of the homogeneity of relative abundances of species in the three types of vegetation of the Atlantic Forest investigated.
To compare the similarity between euglossine fauna from two localities or phytophysiognomies, we used the percentage similarity coefficient of Renkonen, defined as: $\mathrm{PS}=\Sigma \min \left(p^{1}{ }_{\mathrm{i}}, p^{2}{ }_{\mathrm{i}}\right)$, where $p^{1}{ }_{\mathrm{i}}$, is the percentage of species $i$ in sample 1 and $p^{2}{ }_{\mathrm{i}}$ is the percentage of species $i$ in sample 2. This measure of sample similarity is considered one of the best quantitative similarity coefficients because it is not heavily influenced by sample size or species number (Wolda 1981).

The Mann-Whitney test was conducted using the program Graphpad Instat v. 3:06, to determine whether there were significant differences between the abundance and richness among SF and MF areas. Herein, we decided to compare euglossine fauna, since for these both areas the methodology of sampling was exactly the same. The analysis was performed with a significance level set at $95 \%$. This same test was used to evaluate possible differences in bee abundance and richness between two sampling sites in each study area in the three phytophysiognomies, as well as between two different areas of Rainforest at the RNSM. When no significant difference was found, data were grouped, analyzed and shown together.

Air temperature and relative humidity were measured every hour during the collections using a thermo-hygrometer, hung $1.5 \mathrm{~m}$ above the ground. Measures of monthly rainfall for the study areas were obtained from Instituto Agronômico do Paraná (IAPAR).

Correlations between biotic (species of euglossine bees and number of individuals captured monthly and) data and abiotic (temperature, humidity and rainfall) data were tested for significance using PAST 2.17c (Hammer et al. 2001). Values were considered different where $p<0.05$.

To investigate possible influences of abiotic variables of the three different study sites on the relative abundances of the orchid-bee species collected in our study, the canonical correspondence analysis (CCA) was performed in PAST software. In this analysis, the four following variables were considered: monthly mean local temperature and humidity, monthly rainfall and fragment size. For this analysis, we decided not to include altitude measures, since it was reported elsewhere that this abiotic variable can be strongly correlated with mean annual temperature (Nemésio and Vasconcelos 2013).

Finally, aiming to compare the euglossine fauna surveyed in the current study with results obtained in 
nine other studies carried out in 14 different areas of Rainforest and Seasonal Semi-Deciduous Forest remnants of Atlantic Forest located in southern and southeastern Brazil, we performed a Detrended Correspondence Analysis or DCA (Hill and Gauch 1980). For this analysis, a presence-absence matrix of species was built (using original data presented herein and data previously published in ten different studies, listed below). After that, using the software R, version 1.17-6 (R Development Core Team 2011) and "vegan" package 2.0-4 (http://vegan.r-forge.r-project.org/), the data were submitted to DCA (Oksanen et al. 2011). In this analysis, our euglossine faunal surveys were named as PR1RF (corresponding to RNSM area), PR2-SF (FMA; semi-deciduous forest) and PR3-MF (FMA; mixed forest area).

Of the 14 Atlantic Forest areas included in our analysis, ten [RJ1 (Ramalho et al. 2009), PR4 (Mattozo et al. 2011), SP3 and SP4 (Rocha-Filho and Garófalo 2013) and SP6 (Boracéia) SP7 (Neblinas), SP8 (Ilhabela) and SP9 (Cantareira) (Cordeiro et al. 2013) and BA1 and AL1 (Nemésio 2010, 2011)] were carried out in Rainforest (RF) areas and four [SP1 and SP2 (Rebêlo and Garófalo 1997), SP5 (Jesus and Garófalo 2000) and PR5 (Sofia et al. 2004)] in Seasonal Semi-Deciduous Forest (SF) areas. Thus, a total of 17 sites (three from the current study and 14 from these nine other studies) related to the three major types of Atlantic Forest vegetation (RF, SF and MF) were analyzed through the DCA. One of these studies (Ramalho et al. 2009) used exclusively bait traps to survey the euglossine fauna; two others (Mattozo et al. 2011 and Cordeiro et al. 2013) employed both bait traps and insect net methodologies during samplings, while all others used only insect nets. Unidentified species, presented in any of these works as "sp.", were not included in our analysis. Geographical information, such as municipality and geographical coordinates of all areas considered in our analysis were included in Table I-S.

Similarly to those of other authors (Sydney et al. 2010; Mattozo et al. 2011), the two multivariate analyses employed in our study (CCA and DCA) were based on a matrix including only qualitative data (presence-absence).

\section{RESULTS}

In the three studied phytophysiognomies (RF, SF and MF), we collected a total of 744 male euglossine bees, belonging to 15 species and four genera. Of these species, 13 were collected in the RF (RNSM), seven in the SF and only three species in the MF (FMA) (Table I). Besides, at the RNSM, a female of Euglossa anodorhynchi Nemésio was collected in a nest of this species found in an iron pipe, totaling 14 species surveyed in this study area. However, this species was not included in our analyses. As we can notice in Table I, the species collected in the RF area were distributed in four different genera of Euglossini, while the species surveyed in the $\mathrm{SF}$ and in MF were distributed in three different genera.

In $\mathrm{RF}, \mathrm{MF}$ and SF the numbers of individuals collected per sampling hour (or sampling effort) were, respectively: $2.8,1.53$ and 3.9 (Table I).

Three hundred and fifty-five orchid bee males were collected in the Dense Forest area at the RNSM. Euglossa was the most abundant genus in number of individuals, and was better represented in number of species (335 individuals and nine species). Eulaema, represented by two species, was the second most abundant genus (18 individuals), followed by Eufriesea and Exaerete, which were represented by only one individual each (Table I).

In the FMA Seasonal Semi-Deciduous Forest (SF) area, 297 males, belonging to seven species and three euglossine genera, were collected. Euglossa was the most diverse genus, represented by five species, but less abundant in number of males attracted to baits ( $\mathrm{n}=79$ individuals), representing $26.6 \%$ of the total sample (Table I).

In the Mixed Forest area at the FMA, El. nigrita was the most common species, representing $96.7 \%$ of the total sample (Table I).

The estimates of diversity $\left(\mathrm{H}^{\prime}\right)$ found for orchid bee assemblages surveyed in these three phytophysiognomies varied from $0.16(\mathrm{MF})$ to 1.53 (RF), and the evenness (J') measures ranged from 0.15 (MF) to 0.72 (SF) (Table I). The extremely high dominance of El. nigrita in the MF resulted in a high value found for the Berger-Parker index $\left(\mathrm{d}_{\mathrm{BP}}=0.97\right)$ in the studied area, while a lower value of this index $\left(\mathrm{d}_{\mathrm{BP}}=0.4\right)$ was found for both $\mathrm{RF}$ and SF (Table I). Eg. iopoecila and El. nigrita, respectively, were the dominant species, in these two last phytophysiognomies of the Atlantic Forest. 
Table I. Number of males of different species of orchid bee sampled in scent baits in three different phytophysiognomies of Atlantic Forest in southern Brazil. RF $=$ Rainforest; MF $=$ Mixed Forest, and SF $=$ Seasonal SemiDeciduous Forest. Baits: 1- eucalyptol, 2- eugenol, 3- vanillin, 4- beta-ionone, 5- benzyl acetate, 6- benzyl benzoate, 7- methyl salicylate, and 8- methyl cinnamate. ${ }^{*}=$ species that escaped from capture

\begin{tabular}{|c|c|c|c|c|}
\hline Species & DF & SF & MF & Bait \\
\hline Euglossa cordata (Linnaeus 1758) & 5 & 1 & - & 1,4 \\
\hline Euglossa fimbriata Moure 1968 & 2 & 7 & - & 1,6 \\
\hline Euglossa iopoecila Dressler 1982 & 154 & - & - & $1,2,3,4,5,6,7$ \\
\hline Euglossa pleosticta Dressler 1982 & 4 & 14 & - & $1,2,3$ \\
\hline Euglossa roderici Nemésio 2009 & 18 & - & - & $1,2,6,7,8$ \\
\hline Euglossa stellfeldi Moure 1947 & 17 & - & - & $1,2,4$ \\
\hline Euglossa annectans Dressler 1982 & 119 & 47 & - & $1,2,3,4,5,6,7,8$ \\
\hline Euglossa truncata Rebêlo and Moure 1996 & 1 & 10 & - & 1,2 \\
\hline Euglossa viridis (Perty 1833) & 15 & - & - & $1,2,3,6,7$ \\
\hline Euglossa sp* Latreille 1802 & - & - & 1 & 1 \\
\hline Eulaema cingulata (Fabricius 1804) & 6 & - & - & 4,5 \\
\hline Eulaema nigrita Lepeletier 1841 & 12 & 124 & 89 & $1,3,4,5,7$ \\
\hline Eufriesea dentilabris (Mocsáry 1897) & 1 & - & - & 1 \\
\hline Eufriesea violacea (Blanchard 1840) & - & 94 & 2 & 2,3 \\
\hline Exaerete sp* Hoffmannsegg 1817 & 1 & - & - & 1 \\
\hline Total & 355 & 297 & 92 & \\
\hline No. ind/h & 2.82 & 3.91 & 1.53 & \\
\hline H' & 1.53 & 1.40 & 0.16 & \\
\hline $\mathrm{J}^{\prime}$ & 0.60 & 0.72 & 0.15 & \\
\hline$d_{B P}$ & 0.40 & 0.40 & 0.97 & \\
\hline
\end{tabular}

The species accumulation curves for the three studied ecosystems failed to reach an asymptote (Figure 2). On the other hand, whereas the SF and especially MF showed a clear tendency to curve stabilization, the accumulation curve of the RF didn't show this tendency, indicating that an additional number of species is expected in the RF studied area (Figure 2). Particularly for this area, non-parametric richness estimators (Jack 1 and Bootstrap) clearly confirm this expectation, indicating that between 14 and 16 species are estimated for the RF area (Figure 2).

The paired percentage similarity (PS) comparing euglossine assemblages of the three studied phytophysiognomies, calculated with the Renkonen index, varied between $3.8 \%$ (RF x MF) and $44 \%$ (SF x MF). However, taking into account the proximity between the MF and SF areas $(24 \mathrm{~km})$, which are located in the same region and under the same climatic conditions, the percentage similarity (PS) between these two euglossine assemblages can be considered low. A percentage similarity between the RF and SF areas was also low (PS=21.7\%).

Considering the possible influence of mean temperature and humidity taken locally during the samplings and monthly rainfall on bee abundance and species richness surveyed in the three study areas (MF, SF and RF), these two biotic variables were significantly correlated only with temperature and rainfall at RF (Fig. 1S).

The four environmental variables tested (fragment size, mean local temperature, mean local humidity and rainfall) in CCA explained $93 \%$ of the species-habitat relationship, with $72.3 \%$ being accounted for by Axis 1 and $20.7 \%$ by Axis 2 (Fig. 2S). Temperature, humidity and rainfall were among the most important environmental variables influencing the variation in the composition of euglossine bees (Fig. 2S). For a group 


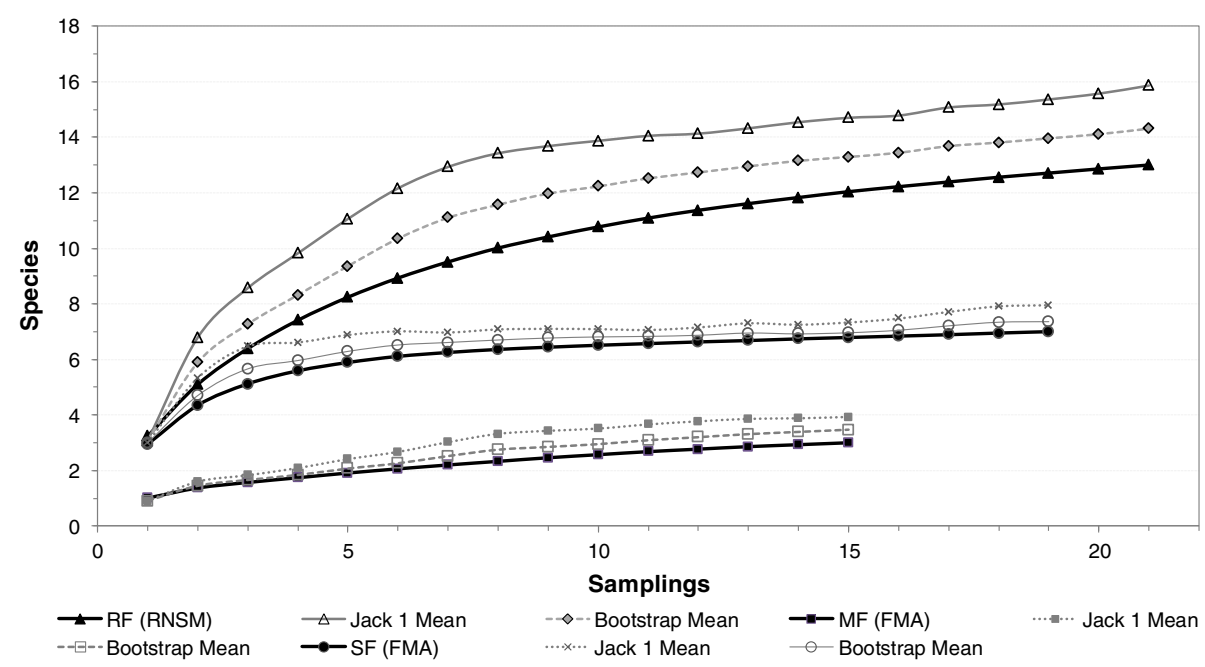

Figure 2 Rarefaction curves of euglossine species plotted against number of samplings in the three phytophysiognomies of Atlantic Forest $(\mathrm{RF}=$ Rainforest, $\mathrm{SF}=$ Seasonal Semi-Deciduous Forest and MF $=$ Mixed Forest $)$ studied in State of Paraná, southern Brazil. Non parametric estimators: Jack 1 mean and Bootstrap mean.

of eight euglossine species (Eg. annectans, El. cingulata, Eg. viridis, Eg. iopoecila, Eg. roderici, Eg. stellfeldi, Ef. dentilabris and Exaerete sp), these three abiotic variables were apparently more closely related to these species; seven of which occurred exclusively in the RF fragment (Table I; Fig. 2S). Particularly, for El. nigrita, the fragment size was the abiotic factor more closely associated to the variance of this species.

A graphic representation obtained through DCA on the variation of the euglossine assemblages surveyed in the current work and nine other studies also involving areas of AF is shown in Fig. 3. The axes 1 and 2 of the DCA explained the most part of the variation found (DCA1: 0.56; DCA2: 0.31). Considering particularly the three areas surveyed in our study (PR1-RF, PR2-SF and PR3-MF), we can notice that PR1-RF appears very close to a group of five other surveys: SP7RF, PR4-RF, SP4-RF, SP8-RF and SP3-RF. More closely positioned to this group of surveys are, among others, the species El. cingulata, Eg. stellfeldi, Eg. roderici and Ef. dentilabris. Following axis 2 (from left to right), we can notice RJ1-RF in an intermediate position, followed by other two studies (BA1-RF and AL1-RF). Euglossa analis Westwood, Eg. despecta Moure, El. bombiformis (Packard) and Eg. gaianii Dressler are among the set of species that appears more closely related to these three studies (RJ1-RF, BA1-RF and AL1$\mathrm{RF})$. Regarding PR2-SF, its close relation to the surveys SP1-SF, PR5-SF, SP5-SF, SP2-SF, SP6$\mathrm{RF}$ and SP9-RF, comprising a 'cluster' of seven studies to which species like Eg. fimbriata, Eg. pleosticta, Eg. truncata, Eg. townsendi and Eg. annectans are apparently more closely linked, is perceptible. Among the surveys included in the DCA, PR3-MF was the one positioned more apart from all others carried out in AF considered herein (Figure 3). Thus, overall, the DCA revealed two main groups of studies carried out throughout Atlantic Forest domain; one group clustering of surveys with species endemic or more associated to coastal areas (including nine from twelve studies carried out in RF), and a second group clustering species more associated to inland areas, although in this latter cluster, not only studies in inland areas of the AF domain were present.

\section{DISCUSSION/CONCLUSION}

This was the first study surveying the orchid bee fauna in RF, SF and MF of Atlantic Forest (AF) remnants across similar latitude and longitude. One the main findings of this study was the remarkable difference between the euglossine bee 


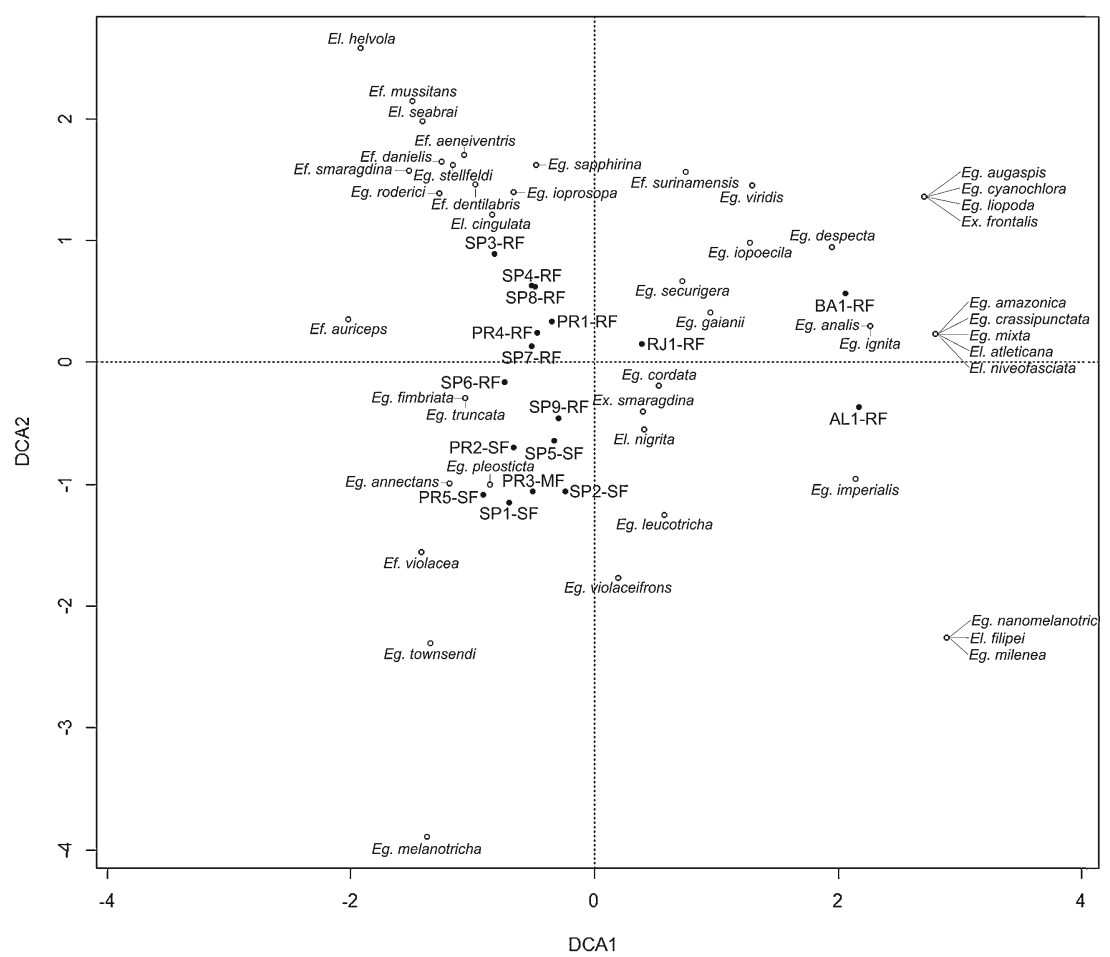

Figure 3 Detrended Correspondence Analysis (DCA) of the orchid bee assemblages throughout the Brazilian Atlantic forest (site codes can be found in the text and in the Table S-I). The three study sites surveyed in the current study are PR1-RF, PR2-SF and PR3-MF. RF = Rainforest; SF = Seasonal Semi-Deciduous Forest; MF = Mixed Forest. PR, SP, RJ, AL and BA correspond to abbreviations of the following Brazilian states, respectively: Paraná, São Paulo, Rio de Janeiro, Alagoas and Bahia. Eg = Euglossa; Ef = Eufriesea; El = Eulaema and Ex = Exaerete.

assemblages present in MF (Mixed Forest) and SF (Semi-Deciduous Forest) located in the same study area. Curiously, despite the large foraging range shown by euglossine bees, which are recognized as strong flyers (Janzen 1971), several species of bees found in the SF were not collected in the MF, although both areas are only $24 \mathrm{~km}$ apart and connected, to a large extent, by areas of Pinus and Eucalyptus. Also, although it has been demonstrated that male euglossine bees are able to cross deforested areas (Raw 1989; Tonhasca et al. 2003), species differ in their ability to travel out of the forest habitat (Milet-Pinheiro and Schlindwein 2005) and explore different habitats (Otero and Sandino 2003). In our study, among the euglossine species surveyed in the SF and MF, El. nigrita is possibly the species with a higher ability to explore and travel across the local landscape. Actually, different authors have indicated that this species is resistant to environmental disturbance (Peruquetti et al. 1999; Tonhasca et al. 2002).

Regardless of the fact that the Mixed Forest (MF) is one the most threatened types of the Brazilian Atlantic Forest ecosystems, only few studies on euglossine assemblages have been conducted in MF forest remnants thus far. For instance, in a survey conducted in a fragment of the MF in the State of Santa Catarina, also in southern Brazil $\left(26^{\circ} 19^{\prime} \mathrm{S} / 50^{\circ} 55^{\prime} \mathrm{W}\right)$, Krug and Alves-dos-Santos (2008) did not collect any male of orchid bees in scent baits in the study area, a forest remnant of about 105 ha. Similarly to our results, Dias (2010) also found low species diversity and an almost absolute dominance of the species E. nigrita in a MF area $\left(25^{\circ} 21^{\prime} \mathrm{S} / 51^{\circ} 58^{\prime}\right.$ $\mathrm{W})$ in the State of Paraná, southern Brazil. In our study, the high dominance of this species in the MF area, along with the low number of species sampled in this type of vegetation 
formation, explain the low value of the Shannon diversity index $\left(\mathrm{H}^{\prime}=0.16\right)$ obtained for the study area.

Bezerra and Martins (2001) postulated that possibly only geographically close areas with similar topography, vegetation and climate present similar euglossine assemblages. Indeed, local abiotic factors (e.g., temperature and humidity) have been related to variations in species richness and composition found in orchid bee assemblages occurring in areas with similar types of vegetation (Andrade-Silva et al. 2012). In our study, while some abiotic variables such as temperature and rainfall were important abiotic factors associated with the euglossine assemblage from RF, the climate was not sufficient to determine a greater similarity between the MF and SF faunas (PS= $44 \%$ ); consequently, to explain the limited similarity between euglossine faunas from MF and SF, which are located under the same climate conditions, other factors should be considered, including possible biological differences among the species. Actually, some euglossine species, such as El. nigrita, have been considered as tolerant to open areas (Peruquetti et al. 1999; Martins and Souza 2005; Milet-Pinheiro and Schlindwein 2005; Aguiar and Gaglianone 2008). According to Martins and Souza (2005), this fact could be related to the greater tolerance to higher temperatures of larger euglossine species compared to the small ones (May and Casey 1983). On the other hand, other euglossine species seem to be more closely bound to, or are at least somehow more dependent on forest habitats (Milet-Pinheiro and Schlindwein 2005).

According to Nemésio (2009), few Atlantic Forest areas have been extensively surveyed in studies of orchid bee fauna. This fact is especially true when we consider the Atlantic Forest areas in southern Brazil. Particularly for RF areas, until this moment, only a few studies on these Neotropical bees have been conducted at a latitude above $25^{\circ} \mathrm{S}$ (Wittmann et al. 1988; Mattozo et al. 2011), revealing a lower richness of this group of bees in relation to those found in areas of RF throughout the Atlantic Forest domain in southeastern (Cordeiro et al. 2013; Rocha-Filho and Garófalo 2013) and northeastern Brazil (Nemésio 2010). Precisely, regarding these three studies, they included rainforest remnants located between $23^{\circ} 21^{\prime} \mathrm{S}$ $44^{\circ} 49^{\prime} \mathrm{W}$ and $23^{\circ} 38^{\prime} \mathrm{S}-45^{\circ} 52^{\prime} \mathrm{W}$, in southeastern Brazil (Cordeiro et al. 2013; Rocha-Filho and Garófalo 2013), and at $09^{\circ} 13$ '23' S - 3552'45" $\mathrm{W}$ in the northeastern region (Nemésio 2010). In fact, euglossine species richness and diversity are expected to be lower at higher latitudes (Mattozo et al. 2011; Abrahamczyk et al. 2011). Besides our study, Mattozo et al. (2011) have also performed a survey of euglossine bees in the APA of Guaraqueçaba, the same region where the RNSM is located. These authors, however, collected only six euglossine species in a remnant forest fragment of about 8,700 ha, also covered by pristine Atlantic Forest, mainly rainforest, located at $25^{\circ} 19^{\prime} \mathrm{S}$ and $48^{\circ} 39^{\prime} \mathrm{W}$. On the other hand, based on data from additional brief euglossine samplings and from generalized bee surveys carried out in the region, they estimated the occurrence of 12 species of these bees in the region of Guaraqueçaba. Our findings, however, showed the incidence of 14 species of orchid bees in both areas of $\mathrm{RF}$ at RNSM (13 captured in baits and one female of Eg. anodorhynchi collected in a nest found in the area), indicating a higher species richness than that estimated by Mattozo et al. (2011). These authors also reported in their study the occurrence of three other species [Eufriesea mussitans (Fabricius 1787), Eufriesea smaragdina (Perty 1833) and Euglossa mandibularis Friese 1899] collected in different surveys; these were not collected in our samplings. Taking our findings together with the reports of Mattozo et al. (2011), the number of euglossine species already recorded for the APA of Guaraqueçaba totals 17 species, which is a number close to that obtained through the non-parametric richness estimates, which estimated between 14 and 16 orchid bee species for the RF area in the RNSM.

It has been reported in the literature that the euglossine fauna of the Atlantic Forest changes noticeably between coastal and inland areas at the same latitude (Mattozo et al. 2011). Our findings are in accordance with this statement. In fact, as shown by these authors, while Euglossa iopoecila, Eg. sapphirina, Eg. roderici and El. cingulata appeared highly associated to coastal area, other orchid bee species such as Eg. truncata, 
Eg. pleosticta and Eg. fimbriata appear to be more associated to inland areas. This finding was deeply corroborated by Detrended Correspondence Analysis herein performed. Thus, the closer association among SP6-RF and SP9-RF with SP1-SF, PR2-SF and PR5-SF surveys than with other studies carried out in coastal areas could be due, at least in part, to the absence both in SP6-RF and SP9-RF of some orchid bee species, such as Eg. iopoecila, Eg. stellfeldi, Eg. sapphirina, Eg. ioprosopa Dressler and Eg. viridis, usually found throughout AF's coastal areas. Finally, the changing in the set of orchid bee species that apparently occurs through the axis 2 of DCA seems to follow a latitudinal gradient, from southern to northeastern. This statement finds support in the study of Sydney et al. (2010), who detected a significant correlation between euglossine assemblages and latitude in neotropics.

In Atlantic Forest areas, particularly concerning those euglossine species that are endemic to the RF vegetation, which is one the most endangered ecosystem of this biome, it is worth emphasizing the high abundance of Eg. iopoecila found in the RSNM. Through the distributional limit of this species, which includes a wide coastal area of the Brazilian territory (Moure et al. 2012), two other studies (Mattozo et al. 2011; Rocha-Filho and Garófalo 2013), also carried out in areas belonging to the Corredor de Biodiversidade da Serra do Mar, have already reported a high abundance of $E g$. iopoecila, as observed in the present study. Apparently, this finding indicates that some remnant areas of RF located at latitudes above $23^{\circ} 21^{\prime} \mathrm{S}$ in the Corredor de Biodiversidade da Serra do Mar are able to maintain large populations of this species.

On the other hand, evidence involving declines in bee diversity worldwide has been accumulating in the last decade (Grixti et al. 2009; Martins and Melo 2010). Amongst the main causes of this fact are habitat loss and fragmentation, use of agricultural pesticides, climate changes and decrease in floral abundance and diversity, resulting from anthropogenic interference (Martins and Melo 2010).
Orchid bees have been considered a group of bees sensitive to deforestation, forest fragmentation and habitat disturbance, showing decline in abundance of some species (Powell and Powell 1987; Giangarelli et al. 2009). Brosi (2009) found a positive relationship between euglossine abundance and forest area. Particularly when we consider the bee diversity in threatened ecosystems, such as the Atlantic Forest (AF), a tropical forest that currently exists mostly in small fragments, about $50 \%$ of which is less than $100 \mathrm{~m}$ distant from the edge (Ribeiro et al. 2009), major concerns regarding bee conservation emerge. The present condition of the AF has led a large expanse of the biodiversity of this Brazilian forest to the threat of extinction (Ribeiro et al. 2009).

It has been suggested that populations of species that dwell close to their distributional limits are more prone to extinction (Martins and Melo 2010). In the current study, besides E. iopoecila, several euglossine species, such as Eufriesea dentilabris, Eg. stellfeldi and Eg. roderici, are endemic to the Atlantic Forest biome and are very close to their southern distributional limit (Moure et al. 2012). As with these orchid bee species, we should remember that other euglossine species (eg. Eg. viridis and Eg. truncata) not endemic to the Atlantic Forest are also close to their southern limit of occurrence (Moure et al. 2012). Considering the high threat condition of the Atlantic Forest remnants (Ribeiro et al. 2009), our findings reinforce the importance of the Corredor de Biodiversidade da Serra do Mar as a biodiversity repository (Aguiar et al. 2003).

Overall, we can conclude that the results obtained in this study significantly contribute to greater knowledge of euglossine assemblages in remnants of Atlantic Forest areas composed of $\mathrm{MF}, \mathrm{SF}$ and $\mathrm{RF}$, helping to further understand how the structure of these bee assemblages can vary significantly at the local and/or regional level. Finally, it is worth emphasizing the importance of extensively studying a particular region to more effectively understand the real diversity of species present on the studied site. 


\section{ACKNOWLEDGMENTS}

This study was funded by Fundação O Boticário de Proteção à Natureza (0848-2009-2), Klabin Papéis e Celulose and CAPES (PROCAD no. 158/2007). We are especially grateful to Dr. André Nemésio (UFU) and Dr. Gabriel A.R. Melo (UFPR) for helping with the species identification. We also thank CAPES for the fellowship granted to the first author; Parana Agronomic Institute (IAPAR) for providing climate data; IBAMA (Brazilian Institute of Environment and Renewable Natural Resources)/ICMBio-System (Institute Chico Mendes - MMA) and IAP (Environmental Institute of Paraná), for permission to collect bees; Universidade Estadual de Londrina, for providing transportation to the study sites; and the Klabin Papéis e Celulose (Telêmaco Borba) local team for its support during the samplings. We would also like to thank Stéphany Watzel, Alessandra N. Alves, Gabriele A. Freiria, Bruno R. Ferrari, Karen M. Suzuki and Henrique Zotarelli for their assistance in field collections and two anonymous reviewers for their helpful comments. Silvia H. Sofia is research fellows from the Brazilian Council for Scientific and Technological Development (CNPq).

Assemblages d'abeilles à orchidée (Hymenoptera: Apidae: Euglossini) à partir de 3 physiognomies de la végétation différentes et menacées de la Forêt Atlantique brésilienne subtropicale

Euglossine / forêt semi-caducifoliée / forêt pluviale tropicale / forêt mixte / forêt néotropicale

Ansammlungen von Prachtbienen (Hymenoptera: Apidae: Euglossini) in drei unterschiedlichen, bedrohten Phytophysiognomien des subtropischen brasilianischen Atlantischen Regenwalds

Euglossine Bienen / saisonaler Halbtrockenwald / tropischer Regenwald / neotropische Wälder

\section{REFERENCES}

Abrahamczyk, S., Gottleuber, C., Matauscheck, C., Kessler, M. (2011) Diversity and community composition of euglossine bee assemblages (Hymenoptera: Apidae) in western Amazonia. Biodivers. Conserv. 20, 29813001

Aguiar, W.M., Gaglianone, M.C. (2008) Comunidade de abelhas Euglossina (Hymenoptera: Apidae) em remanescentes de mata estacional semidecidual sobre Tabuleiro no estado do Rio de Janeiro. Neotropical Entomol. 37, 118-125
Aguiar, A.P., Chiarello, A.G., Mendes, S.L., de Matos, E.M. (2003) The Central and Serra do Mar Corridors in the Brazilian Atlantic Forest. In: Galindo-Leal, C., Câmara, I.G. (eds.) The Atlantic Forest of South America: Biodiversity, threats and outlook (State of the Hotspots), pp. 118-132. Island Press, Washington D.C

Andrade-Silva, A.C.R., Nemésio, A., Oliveira, F.F., Nascimento, F.S. (2012) Spatial-temporal variation in orchid bee communities (Hymenoptera: Apidae) in remnants of arboreal Caatinga in the Chapada Diamantina region, State of Bahia, Brazil. Neotropical Entomol. 41, 296-305

Bezerra, C.P., Martins, C.F. (2001) Diversidade de Euglossinae (Hymenoptera, Apidae) em dois fragmentos de Mata Atlântica localizados na região urbana de João Pessoa, Paraíba, Brasil. Rev. Bras. Zool. 18, 823-825

Brosi, B.J. (2009) The effects of forest fragmentation on euglossine bee communities (Hymenoptera: Apidae: Euglossini). Biol. Conserv. 142, 414-423

Colwell, R.K. (2006) Estimate S: Statistical estimation of species richness and shared species from samples. Version 8. URL http://www.purl.oclc.org/estimates

Cordeiro, G.D., Boff, S., Caetano, T.A., Fernandes, P.C., Alves-dos-Santos, I. (2013) Euglossine bees (Apidae) in Atlantic forest areas of São Paulo State, southeastern Brazil. Apidologie 44, 254-267

Dias, F.V. (2010) Ocorrência de Euglossina (Hymenoptera: Apidae) em um fragmento de Floresta Ombrófila Mista no Centro-Sul do Paraná, Brasil. Master Dissertation, Universidade Estadual do Centro-Oeste

Faria Jr., L.R.R., Melo, G.A.R. (2012) Species of Euglossa of the analis group in the Atlantic forest (Hymenoptera, Apidae). Zoologia 29, 349-374

Galindo-Leal, C., Câmara, I.G. (2003) The Atlantic Forest of South America: Biodiversity, threats and outlook (State of the Hotspots). Island Press, Washington D.C

Giangarelli, D.C., Sofia, S.H. (2011) First record of the orchid bee Euglossa viridis (Perty) (Hymenoptera, Apidae, Euglossini) from Paraná State, southern Brazil. Braz. J. Biol. 71, 223

Giangarelli, D.C., Freiria, G.A., Colatreli, O.P., Suzuki, K.M., Sofia, S.H. (2009) Eufriesea violacea (Blanchard) (Hymenoptera: Apidae): an orchid bee apparently sensitive to size reduction in forest patches. Neotropical Entomol. 38, 1-6

Grixti, J.C., Wong, L.T., Cameron, S.A., Favret, C. (2009) Decline of bumble bees (Bombus) in the North American Midwest. Biol. Conserv. 142, 75-84

Hammer, Ø., Harper, D.A.T., Ryan, P.D. (2001) PAST paleontological statistics software package for education and data analysis. Paleontol. Electron. 4, 1-9

Hill, M.O., Gauch Jr., H.G. (1980) Detrended correspondence analysis: An improved ordination technique. Vegetation 42, 47-58

Janzen, D.H. (1971) Euglossine bees as long-distance pollinators of tropical plants. Science 171, 203-205

Jesus, B.M.V., Garófalo, C.A. (2000) Riqueza e abundância sazonal de Euglossini (Hymenoptera, Apidae) na Mata 
da Virgínia, Matão, São Paulo. In: IV Encontro Sobre Abelhas, Anais, São Francisco Gráfica e Editora, Ribeirão Preto, pp 239-245

Krug, C., Alves-dos-Santos, I. (2008) O uso de diferentes métodos para amostragem da fauna de abelhas (Hymenoptera: Apoidea), um estudo em Floresta Ombrófila Mista em Santa Catarina. Neotropical Entomol. 37, 265-278

Ludwig, J.A., Reynolds, J.F. (1988) Statistical ecology: a primer of methods and computing. Wiley Press, New York

Martins, A.C., Melo, G.A.R. (2010) Has the bumblebee Bombus bellicosus gone extinct in the northern portion of its distribution range in Brazil? J. Insect Conserv. 14, 207-210

Martins, C.F., Souza, A.K.P. (2005) Estratificação vertical de abelhas Euglossina (Hymenoptera, Apidae) em uma área de Mata Atlântica, Paraíba, Brasil. Rev. Bras. Zool. 22, 913-918

Mattozo, V.C., Faria, L.R.R., Melo, G.A.R. (2011) Orchid bees (Hymenoptera: Apidae) in the coastal forests of southern Brazil: diversity, efficiency of sampling methods and comparison with other Atlantic forest surveys. Pap. Avulsos Zool. 51, 505-515

May, M.L., Casey, T.M. (1983) Thermoregulation and heat exchange in euglossines bees. Physiol. Zool. 56, 541551

Milet-Pinheiro, P., Schlindwein, C. (2005) Do euglossine males (Apidae, Euglossini) leave tropical rainforest to collect fragrances in sugarcane monocultures? Rev. Bras. Zool. 22, 853-858

Miretzki, M. (2003) Morcegos do Estado do Paraná, Brasil (Mammalia, Chiroptera): riqueza de espécies, distribuição e síntese do conhecimento atual. Pap. Avulsos Zool. 43, 101-138

Morellato, L.P.C., Haddad, C.F.B. (2000) Introduction: The Brazilian Atlantic Forest. Biotropica 32, 786-792

Moure, J.S., Melo, G.A.R., Faria, L.R.R. Jr (2012) Euglossini Latreille, 1802. In: Moure, J.S., Urban, D., Melo, G.A.R. (Orgs.) Catalogue of Bees (Hymenoptera, Apoidea) in the Neotropical Region - online version. Available at http://www.moure.cria.org.br/catalogue. Accessed 18 August 2013

Myers, N., Mittermeier, R.A., Mittermeier, C.G., Fonseca, G.A.B.., Kent, J. (2000) Biodiversity hotspots for conservation priorities. Nature 403, 853-858

Nemésio, A. (2009) Orchid bees (Hymenoptera: Apidae) of the Brazilian Atlantic Forest. Zootaxa 2041, 1-242

Nemésio, A. (2010) The orchid-bee fauna (Hymenoptera: Apidae) of a forest remnant in northeastern Brazil, with new geographic records and an identification key to the known species of the Atlantic Forest of northeastern Brazil. Zootaxa 2656, 55-66

Nemésio, A. (2011) The orchid-bee fauna (Hymenoptera: Apidae) of a forest remnant in southern Bahia, Brazil, with new geographic records and an identification key to the known species of the area. Zootaxa 2821, 47-54
Nemésio, A. (2012) The western limits of the "Hileia Baiana" for orchid bees, including seven new records for the state of Minas Gerais, eastern Brazil. Spixiana 35, 109-116

Nemésio, A., Vasconcelos, H.L. (2013) Beta diversity of orchid bees in a tropical biodiversity hotspot. Biodivers. Conserv. 22, 1647-1661

Oksanen, J., Blanchet, F.G., Kindt, R., Legendre, P., O’Hara, R.B., Simpson, G.L., Solymos, P., Stevens, M.H.H., Wagner, H. (2011) Vegan: community ecology package. R package version 1.17-6. http:/CRAN.Rproject.org/package=vegan. Accessed 15 August 2013

Otero, J.T., Sandino, J.C. (2003) Capture rates of male euglossine bees across a human intervention gradient, Chocó region, Colombia. Biotropica 35, 520-529

Peruquetti, R.C., Campos, L.A.O., Coelho, C.D.P., Abrantes, C.V.M., Lisboa, L.C.O. (1999) As abelhas Euglossini (Apidae) de áreas de Mata Atlântica: abundância, riqueza e aspectos biológicos. Rev. Bras. Zool. 16, 101-118

Petersen, M.J., Courtney, G.W. (2010) Landscape heterogeneity and the confluence of regional faunas promote richness and structure community assemblage in a tropical biodiversity hotspot. J. Insect Conserv. 14, 181-189

Powell, A.H., Powell, V.N. (1987) Population dynamics of male euglossine bees in Amazonian forest fragments. Biotropica 19, 176-179

R Development Core Team (2011) R: A language and environment for statistical computing. R Foundation for Statistical Computing, Vienna. ISBN 3-900051-070, URL http://www.R-project.org/ Accessed $15 \mathrm{Au}-$ gust 2013

Ramalho, A.V., Gaglianone, M.C., Oliveira, M.L. (2009) Comunidades de abelhas Euglossina (Hymenoptera, Apidae) em fragmentos de Mata Atlântica no Sudeste do Brasil. Rev. Bras. Entomol. 53, 95-101

Raw, A. (1989) The dispersal of euglossine bees between isolated patches of eastern Brazilian wet forest (Hymenoptera: Apidae). Rev. Bras. Entomol. 33, 103-107

Rebêlo, J.M.M., Garófalo, C.A. (1991) Diversidade e sazonalidade de machos de Euglossini (Hymenoptera, Apidae) e preferências por iscas-odores em um fragmento de floresta no sudeste do Brasil. Rev. Bras. Biol. 51, 787-799

Rebêlo, J.M.M., Garófalo, C.A. (1997) Comunidades de machos de Euglossini (Hymenoptera: Apidae) em matas semidecíduas do nordeste do Estado de São Paulo. Ann. Soc. Entomol. Bras. 26, 243-255

Reis, N.R., Peracchi, A.L., Fandinõ-Marinõ, H., Rocha, V.J. (2005) Mamíferos da Fazenda Monte Alegre Paraná. Eduel, Londrina

Ribeiro, M.C., Metzger, J.P., Martensen, A.C., Ponzoni, F.J., Hirota, M.M. (2009) The Brazilian Atlantic Forest: How much is left, and how is the remaining forest distributed? Implications for conservation. Biol. Conserv. 142, 1141-1153

Rocha-Filho, L.C., Garófalo, G. (2013) Community ecology of euglossine bees in the coastal Atlantic Forest of São Paulo State, Brazil. J. Insect Sci. 13(article 13), 1-19 
Roubik, D.W., Hanson, P.H. (2004) Orchid Bees of Tropical America, 1st edn. INBio, Santo Domingo de Heredia, Costa Rica

Santos-Pereira, M., Candaten, A., Milani, D., Oliveira, F.B., Gardelin, J., da Rocha, C.F.D. (2011) Seasonal variation in the leaf-litter frog community (Amphibia: Anura) from an Atlantic Forest Area in the Salto Morato Natural Reserve, southern Brazil. Zoologia 28, 755-761

Sofia, S.H., Santos, A.M., Silva, C.R.M. (2004) Euglossine bees (Hymenoptera, Apidae) in a remnant of Atlantic Forest in Paraná State, Brazil. Iheringia 94, 217-222

Straube, F.C., Urben-Filho, A. (2005) Avifauna da Reserva Natural Salto Morato (Guaraqueçaba, Paraná). Atual. Ornitol. 124, 12-21

Sydney, N.V., Gonçalves, R.B., Faria, L.R.R. (2010) Padrões espaciais na distribuição de abelhas
Euglossina (Hymenoptera, Apidae) da região Neotropical. Pap. Avulsos Zool. 50, 693-699

Tonhasca Jr., A., Blackmer, J.L., Albuquerque, G.S. (2002) Abundance and diversity of euglossine bees in the fragmented landscape of the Brazilian Atlantic Forest. Biotropica 34, 416-422

Tonhasca Jr., A., Albuquerque, G.S., Blackmer, J.L. (2003) Dispersal of euglossine bees between fragments of the Brazilian Atlantic Forest. J. Trop. Ecol. 19, 99-102

Wittmann, D., Hoffmann, M., Scholz, E. (1988) Southern distributional limits of euglossine bees in Brazil linked to habitats of the Atlantic and subtropical rain forest (Hymenoptera: Apidae: Euglossini). Entomol. Gen. 14, 53-60

Wolda, H. (1981) Similarity indices, sample size and diversity. Oecologia 50, 296-302

Wright, S.J. (2005) Tropical forests in a changing environment. Trends Ecol. Evol. 20, 553-560 